\title{
Reduction of Nitrogen Oxide Using a Perovskite-type Protonic Conductor $\mathrm{SrZr}_{0.9} \mathrm{Yb}_{0.1} \mathrm{O}_{3-\alpha}$
}

\author{
Tetsuro KOBAYASHI, * Katsushi ABE, Yoshio UKYO, and Hiroyasu IWAHARAa
}

Toyota Central R\&D Labs., Inc. (Nagakute, Aichi 480-1192, Japan)

${ }^{a}$ Center for Integrated Research in Science and Engineering, Nagoya University (Furo-cho, Chikusa-ku, Nagoya 4648603, Japan)

Received November 30, 1999 ; Accepted February 10, 2000

\begin{abstract}
A steam electrolysis cell was constructed with a perovskite-type protonic conductor, $\mathrm{Sr} \mathrm{Zr}_{0.9} \mathrm{Yb}_{0.1} \mathrm{O}_{3-\alpha}$, as an electrolyte. The steam electrolysis cell efficiently produced hydrogen in the temperature range from 400 to $600^{\circ} \mathrm{C}$. The application of this cell to reduce nitrogen oxide (NO) by the hydrogen was examined. When $\mathrm{Pt} / \mathrm{Ba} / \mathrm{Al}_{2} \mathrm{O}_{3}$ catalyst was employed on the cathode, the cell could reduce NO even in $\mathrm{O}_{2}$-rich atmosphere. The cathode potential of the cell revealed that the reduction of $\mathrm{O}_{2}$ might be inhibited due to the absorption of $\mathrm{NO}$ and $\mathrm{O}_{2}$ into $\mathrm{Ba}$, and that $\mathrm{NO}$ absorbed in Ba might be reduced to $\mathrm{N}_{2}$ by atomic hydrogen.
\end{abstract}

Key Words : Protonic Conductor, Nitrogen Oxide, Reduction, Steam Electrolysis

\section{Introduction}

$\mathrm{SrCe}_{0.95} \mathrm{Yb}_{0.05} \mathrm{O}_{3-\alpha}, \quad \mathrm{BaCe}_{0.8} \mathrm{Gd}_{0.2} \mathrm{O}_{3-\alpha}$, and $\mathrm{SrZr}_{0.9} \mathrm{Yb}_{0.1}$. $\mathrm{O}_{3-\alpha}$ ( $\alpha$; mole fraction of oxide ion vacancies) with the perovskite-type structure have oxide ion vacancies, and $\mathrm{H}_{2} \mathrm{O}$ can be dissolved into the crystal structure according to equation (1), ${ }^{1}$ )

$$
\mathrm{H}_{2} \mathrm{O}+\mathrm{V}_{\mathrm{O}}{ }^{\cdot} \rightarrow 2 \mathrm{H}^{\cdot}+\mathrm{O}^{\times}
$$

where $\mathrm{V}_{\mathrm{O}}$ " denotes an oxide ion vacancy, $\mathrm{H}^{\cdot}$ a proton and $\mathrm{O}_{0}{ }^{\times}$an oxide ion at a normal lattice site. ${ }^{2,3)} \mathrm{H}_{2} \mathrm{O}$ dissolved in the perovskite structure forms protons combined with oxide ions at the normal lattice sites by $\mathrm{OH}$ bond. ${ }^{4}$ 'This proton can migrate around semi-stable positions near oxide ions by the hopping conduction mechanism $^{5)}$ and may lead to a high ionic conductivity $\left(\fallingdotseq 10^{-3}\right.$ $(\mathrm{S} / \mathrm{cm})$ ) of these materials around $\left.700^{\circ} \mathrm{C} .{ }^{1}\right)$

These materials with a high protonic conductivity have been studied widely for their applications including hydrogen sensors, ${ }^{6-10)}$ SOFCs $^{1-15)}$ and gas reactors. ${ }^{16-18)}$ We have studied on a new device using this protonic conductor in order to reduce nitrogen monoxide (NO), ${ }^{19}$ ) which is one of the most harmful components in exhaust gases of automobiles, because most of nitrogen oxides $\left(\mathrm{NO}_{x}\right)$ exist as $\mathrm{NO}$ in the exhaust gases. To date, chemical catalysts have been mainly used to reduce NO by hydrocarbons and $\mathrm{CO}$ in the exhaust gas. However, this method is not effective under the lean-burn $\left(\mathrm{O}_{z}\right.$-rich) condition. Therefore, the development of new methods is required for the effective reduction of NO even under such lean-burn conditions. In this study, we investigate an electrochemical method using a steam electrolysis cell for reducing NO.

Figure 1 shows a schematic diagram of a steam electrolysis cell for reducing NO. The steam electrolysis cell is constructed with a solid protonic conductor as the electrolyte. Water vapor is electrochemically oxidized on the anode and the protons produced are transported through the electrolyte to the cathode. At the cathode, protons are first reduced to atomic hydrogen, and then hydrogen gases are produced. Therefore, in this cell, it is expected that NO will be reduced not only electrochemically but also chemically. In this system, water vapor in the exhaust gases can be used as a water source for the anode. Therefore, this cell can be a simple and effective device for NO reduction in exhaust gases.

The following reactions may be relevant in such kinds of cells:

$$
\begin{aligned}
& 2 \mathrm{NO}(\mathrm{g})+2 \mathrm{H}^{+}+2 \mathrm{e}^{-} \longrightarrow \mathrm{N}_{2} \mathrm{O}(\mathrm{g})+\mathrm{H}_{2} \mathrm{O}(\mathrm{g}) \\
& 2 \mathrm{NO}(\mathrm{g})+4 \mathrm{H}^{+}+4 \mathrm{e}^{-} \longrightarrow \mathrm{N}_{2}(\mathrm{~g})+2 \mathrm{H}_{2} \mathrm{O}(\mathrm{g}) \\
& \mathrm{NO}(\mathrm{g})+5 \mathrm{H}^{+}+5 \mathrm{e}^{-} \longrightarrow \mathrm{NH}_{3}(\mathrm{~g})+\mathrm{H}_{2} \mathrm{O}(\mathrm{g}) \\
& \mathrm{O}_{2}(\mathrm{~g})+4 \mathrm{H}^{+}+4 \mathrm{e}^{-} \longrightarrow 2 \mathrm{H}_{2} \mathrm{O}(\mathrm{g}) \\
& \mathrm{Ba}\left(\mathrm{NO}_{3}\right)_{2}(\mathrm{~s})+10 \mathrm{H}^{+}+10 \mathrm{e}^{-} \\
& \longrightarrow \mathrm{BaO}(\mathrm{s})+\mathrm{N}_{2}(\mathrm{~g})+5 \mathrm{H}_{2} \mathrm{O}(\mathrm{g})
\end{aligned}
$$

The electrochemical reactions between NO and proton may be written as equations (2) (4). The electrochemical reaction between $\mathrm{O}_{2}$ and proton may be written as equation (5), which competes with reactions $(2) \sim(4)$.

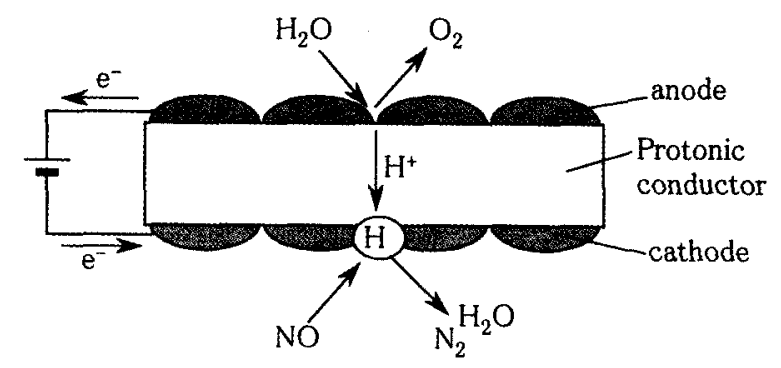

Fig. 1 Schematic diagram of a steam electrolysis cell for the reduction of nitrogen oxide. 
When an electrocatalyst based on $\mathrm{Ba}$, capable to absorb NO, is set on the cathode of the cell, the related electrochemical reaction may be written as equation (6).

Figure 2 shows the temperature dependence of the standard potential of each electrochemical reaction versus reversible hydrogen potential (RHE). Because the reduction reactions with higher standard potentials usually proceed first, it is expected that NO will be reduced easier than $\mathrm{O}_{2}$ according to equations (2) and (3).

\section{Experimental}

Figure 3 shows a cross section of the experimental apparatus. A closed one-end tube of sintered $\mathrm{SrZr}_{0.9} \mathrm{Yb}_{0.1} \mathrm{O}_{3-\alpha^{20)}}$ (supplied from TYK corp.) was used as the protonic conductor. This protonic conductor is chemically more stable than other protonic conductors based on $\mathrm{SrCeO}_{3}$ and $\mathrm{BaCeO}_{3}$ in an atmosphere containing $\mathrm{CO}_{2},{ }^{21)}$ which is one of the components in the exhaust gas. Platinum for electrodes was plated on both sides of the electrolyte by an electroless plating method. The areas of the anode and the cathode were $6 \mathrm{~cm}^{2}$ and $5 \mathrm{~cm}^{2}$, respectively. The thickness of both electrodes was about $2 \mu \mathrm{m}$.

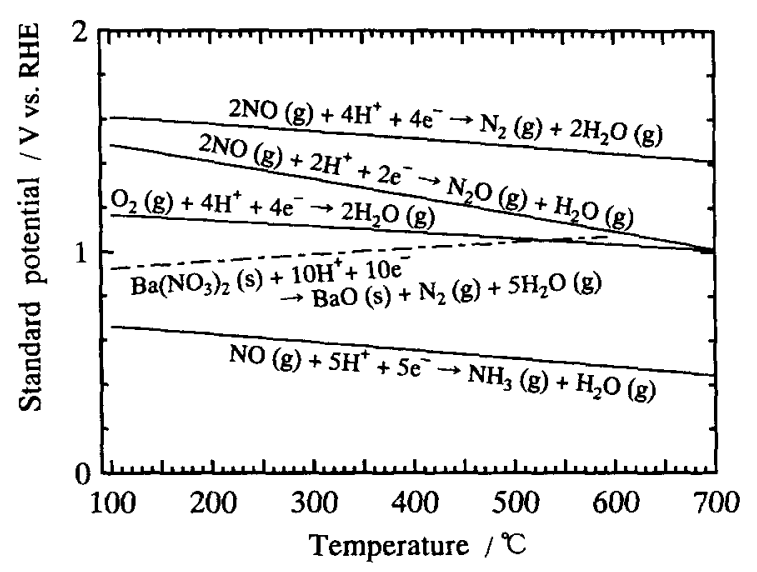

Fig. 2 Standard potential versus reversible hydrogen potential (RHE) for each electrochemical reaction.

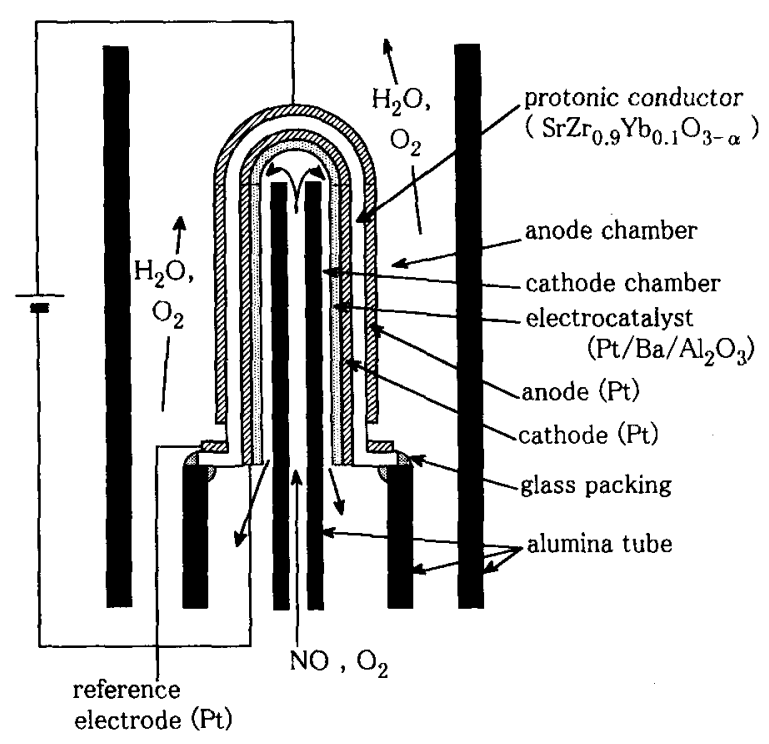

Fig. 3 Cross-section of the experimental apparatus.
$\mathrm{Pt} / \mathrm{Ba} / \mathrm{Al}_{2} \mathrm{O}_{3}$ catalyst ${ }^{22,23)}$ was set on the Pt plated cathode for the reduction of $\mathrm{NO}$ under $\mathrm{O}_{z}$-rich conditions. $\mathrm{Pt}$ $/ \mathrm{Ba} / \mathrm{Al}_{2} \mathrm{O}_{3}$ was prepared by the following process: $\gamma-\mathrm{Al}_{2} \mathrm{O}_{3}$ powder was added into platinum dinitro diammine solution and stirred for $3 \mathrm{hrs}$. After evaporating the water, the resulting powder was calcined in air at $300^{\circ} \mathrm{C}$ for $3 \mathrm{hrs}$. The powder was put into barium acetate solution and treated in the same way to obtain $\mathrm{Pt} / \mathrm{Ba} / \mathrm{Al}_{2} \mathrm{O}_{3}$ catalyst. The composition of this catalyst was $1.2 \mathrm{wt} \% \mathrm{Pt}$, $25.1 \mathrm{wt} \% \mathrm{Ba}$ and $73.7 \mathrm{wt} \% \mathrm{Al}_{2} \mathrm{O}_{3}$. Because the specific surface area of $\gamma-\mathrm{Al}_{2} \mathrm{O}_{3}$ powder was about $170 \mathrm{~m}^{2} / \mathrm{g}$, Pt and $\mathrm{Ba}$ were considered to be dispersed well on $\gamma-\mathrm{Al}_{2} \mathrm{O}_{3}$. By XRD measurement, it was revealed that $\mathrm{Ba}$ on the catalyst existed as $\mathrm{BaCO}_{3}$. $\mathrm{Pt} / \mathrm{Ba} / \mathrm{Al}_{2} \mathrm{O}_{3}$ catalyst and $\mathrm{Pt}$ paste (U-3820, N.E. Chemcat corp.) were mixed well, and then spread on the Pt plated cathode, and finally calcined at $800^{\circ} \mathrm{C}$. After the calcination, the weight fractions of $\mathrm{Pt} /$ $\mathrm{Ba} / \mathrm{Al}_{2} \mathrm{O}_{3}$ catalyst and $\mathrm{Pt}$ of $\mathrm{Pt}$ paste were $17 \mathrm{wt} \%$ and 83 wt $\%$, respectively. The amount of $\mathrm{Pt} / \mathrm{Ba} / \mathrm{Al}_{2} \mathrm{O}_{3}$ catalyst was $60 \mathrm{mg}$.

The anode chamber and cathode chamber were constructed as shown in Fig.3. The gas mixture with $90 \%$ $\mathrm{H}_{2} \mathrm{O}$ and $10 \%$ air was introduced into the anode chamber at a rate of $200 \mathrm{ml} / \mathrm{min}$. The reference electrode in this gas showed the equilibrium potential among $\mathrm{H}_{2} \mathrm{O}, \mathrm{O}_{2}$ and proton, according to equation (7).

$$
\mathrm{O}_{2}(\mathrm{~g})+4 \mathrm{H}^{+}+4 \mathrm{e}^{-} \rightleftarrows 2 \mathrm{H}_{2} \mathrm{O}(\mathrm{g})
$$

Inert gases with or without $\mathrm{NO}$ and $\mathrm{O}_{2}$ were introduced to the cathode at a rate of $30 \mathrm{ml} / \mathrm{min}$. Direct current was applied galvanostatically to the cell. Experiments were carried out in the temperature range from 400 to $600^{\circ} \mathrm{C}$ at the atmospheric pressure. Gas chromatography with porapak $\mathrm{Q}$ and molecular sieve $5 \mathrm{~A}$ columns was used to analyze the concentrations of $\mathrm{H}_{2}, \mathrm{~N}_{2}$, $\mathrm{O}_{2}$ and $\mathrm{N}_{2} \mathrm{O}$. The concentrations of $\mathrm{NO}_{x}$ and $\mathrm{NH}_{3}$ were measured by Saltzman method and an absorbing-type gas detector (GASTEC Co. No.3L, 3M), respectively.

\section{Results and Discussion}

The results of the cell without catalyst, for which the cathode was pure Pt plated electrode, are described first. Pure Ar gas was introduced to the cathode as a carrier gas. The $\mathrm{H}_{2}$-production rate was measured at $450^{\circ} \mathrm{C}$, and the result is shown in Fig. 4. The broken line represents $100 \%$ efficiency determined by Faraday's law. The efficiency higher than $90 \%$ was obtained for the current densities between 0 and $4 \mathrm{~mA} \mathrm{~cm}{ }^{-2}$. The same results were obtained at all temperatures under investigation. These results indicate that the present system can efficiently produce hydrogen which could be used as a reducing agent for NO.

Figure 5 shows the dependence of the NO-removal efficiency on current density when He gas containing 1000 ppm NO was introduced to the cathode at $450^{\circ} \mathrm{C}$. The NO-removal efficiency is defined as the ratio of the amount of removed NO to that of supplied NO according to equation (8).

NO-removal efficiency $=$ removed $\mathrm{NO} /$ supplied $\mathrm{NO}(8)$ 


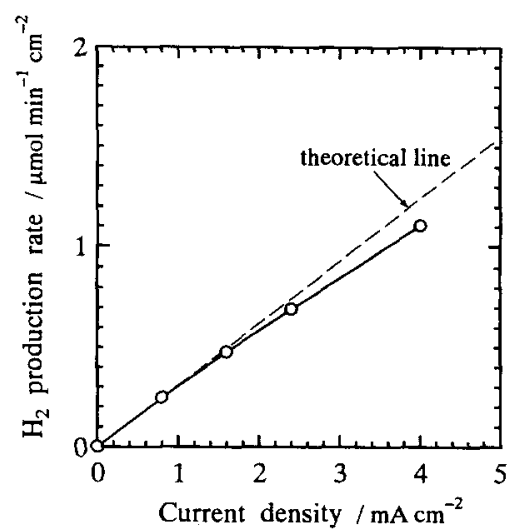

Fig. 4 Change in $\mathrm{H}_{2}$ production rate with current density. Temp.: $450^{\circ} \mathrm{C}$. The broken line represents $100 \%$ efficiency determined by Faraday's law.

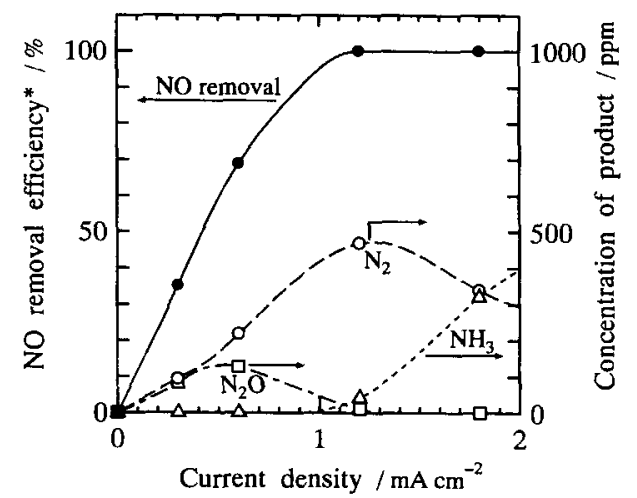

Fig. 5 Change in NO removal efficiency* and concentrations of the products with current density. Feed gas: 1000 ppm NO in He. Temp.: $450^{\circ} \mathrm{C} .{ }^{*} \mathrm{NO}$ removal efficiency = Removed NO /Supplied NO.

The efficiency increased with increasing current density, and reached to $100 \%$ at current densities higher than $1.2 \mathrm{~mA} \mathrm{~cm}{ }^{-2}$. The main products were $\mathrm{N}_{2} \mathrm{O}$ and $\mathrm{N}_{2}$ at low current densities, and $\mathrm{N}_{2}$ and $\mathrm{NH}_{3}$ at high current densities. The total amount of nitrogen in the products was equal to that of the removed NO.

Figure 6 shows $\mathrm{NO}$ - and $\mathrm{O}_{2}$-removal efficiencies when $\mathrm{He}$ gas containing $1000 \mathrm{ppm} \mathrm{O}_{2}$ and $1000 \mathrm{ppm} \mathrm{NO}$ was introduced to the cathode at $450^{\circ} \mathrm{C}$. At lower current densities, the reduction of $\mathrm{O}_{2}$ was predominant. NO reduction started at current densities higher than $1.6 \mathrm{~mA} \mathrm{~cm}-2$ at which most of $\mathrm{O}_{2}$ was removed. The reaction products of the NO reduction were similar to those of Fig. 5. The total amount of nitrogen in the products was also equal to that of the removed NO. The preferable reduction of $\mathrm{O}_{2}$ to $\mathrm{NO}$ was observed throughout the experimental temperature range.

The current dependence of cathode potentials against the reference electrode is shown in Fig. 7. The cathode potentials of the cell for reducing $\mathrm{NO}$ and $\mathrm{O}_{2}$ were higher than those of the cell for producing $\mathrm{H}_{2}$. This suggests that $\mathrm{NO}$ and $\mathrm{O}_{2}$ were not chemically reduced by $\mathrm{H}_{2}$ gas. Therefore, $\mathrm{NO}$ and $\mathrm{O}_{2}$ are considered to be electrochemically reduced by protons according to equations (2) (5), or chemically reduced by atomic hydrogen adsorbed on Pt. As shown in Fig.2, NO was expected to be

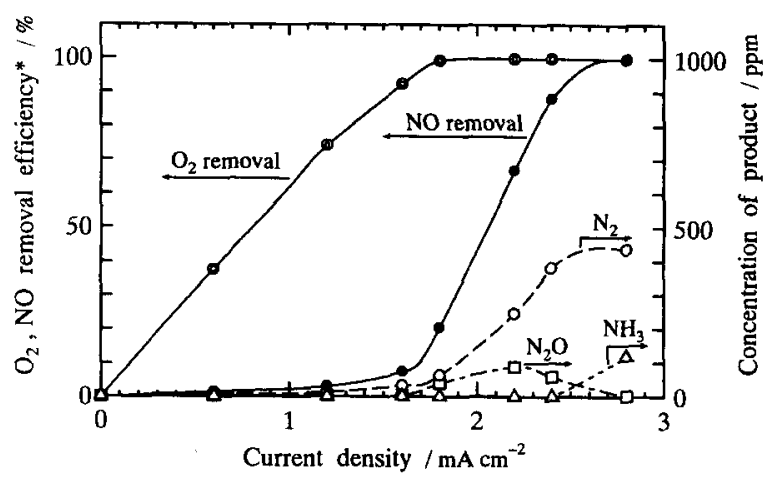

Fig. 6 Change in $\mathrm{O}_{2}$ and NO removal efficiency* and concentrations of the products with current density. Feed gas: 1000 ppm $\mathrm{O}_{2}$ and 1000 ppm $\mathrm{NO}$ in He. Temp.: $450^{\circ} \mathrm{C} .{ }^{*} \mathrm{O}_{2}$ (NO) removal efficiency $=$ Removed $\mathrm{O}_{2}$ (NO)/Supplied $\mathrm{O}_{2}$ (NO).

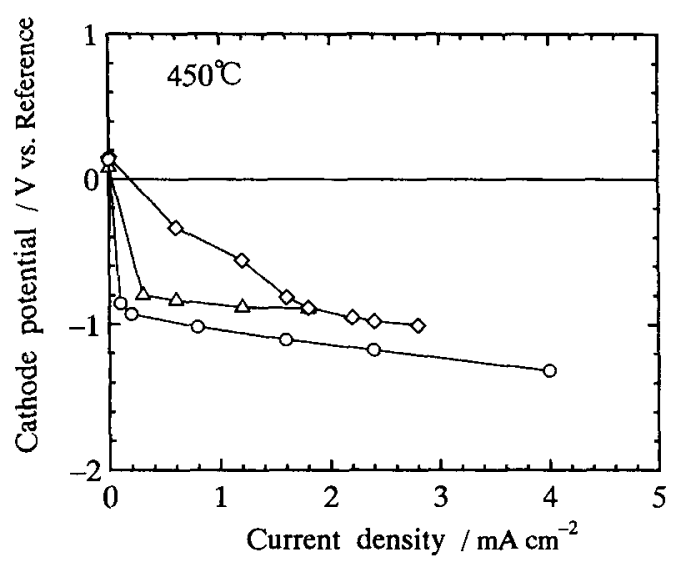

Fig. 7 Current dependence of cathode potential at $450^{\circ} \mathrm{C}$. $\bigcirc$ $: \mathrm{H}_{2}$ production (Feed gas: pure Ar), $\triangle:$ NO reduction (Feed gas: $1000 \mathrm{ppm} \mathrm{NO}$ in $\mathrm{He}$ ), $\diamond: \mathrm{O}_{2}$ and NO reduction (Feed gas: $1000 \mathrm{ppm} \mathrm{O}_{2}$ and $1000 \mathrm{ppm} \mathrm{NO}$ in $\mathrm{He}$ ).

reduced easier than $\mathrm{O}_{2}$. However, the experimental results showed that $\mathrm{O}_{2}$ was reduced easier than NO. It seems that the activation energy for NO reduction is very high.

Figure 8 shows the temperature dependence of the NO-removal efficiency when $\mathrm{He}$ gas containing $8 \% \mathrm{O}_{2}$ and $1000 \mathrm{ppm}$ NO $\left(\mathrm{O}_{2} / \mathrm{NO}=80\right)$ was introduced to the cathode. The concentrations of $\mathrm{O}_{2}$ and NO correspond to those of exhaust gases from combustion engines operating under the lean-burn condition with the air-fuel ratio of about 20 . The current density was $2.4 \mathrm{~mA} \mathrm{~cm}$ c $^{-2}$. If $\mathrm{H}_{2}$ gas is produced in this atmosphere containing $\mathrm{O}_{2}$ and $\mathrm{NO}$, the amount of $\mathrm{H}_{2}$ gas produced at this current density will be three times of the amount of NO and only one-twenty seventh of the amount of $\mathrm{O}_{2}$ in the cathode gas.

NO was not removed at the pure Pt plated cathode, as shown in Fig.8 (open-circle). In the cell with the $\mathrm{Pt} / \mathrm{Ba}$ / $\mathrm{Al}_{2} \mathrm{O}_{3}$ catalyst on the $\mathrm{Pt}$ plated cathode, however, NO could be removed. The NO-removal efficiency reached up to $20 \%$ at $400^{\circ} \mathrm{C} . \mathrm{N}_{2}$ and $\mathrm{N}_{2} \mathrm{O}$ were detected in the outlet gas as products of the $\mathrm{NO}$ reduction and $\mathrm{NH}_{3}$ was not detected. The NO-removal rate and the $\mathrm{N}_{2-}$ and $\mathrm{N}_{2} \mathrm{O}$ formation rates were plotted in Fig. 9. The NO-removal 


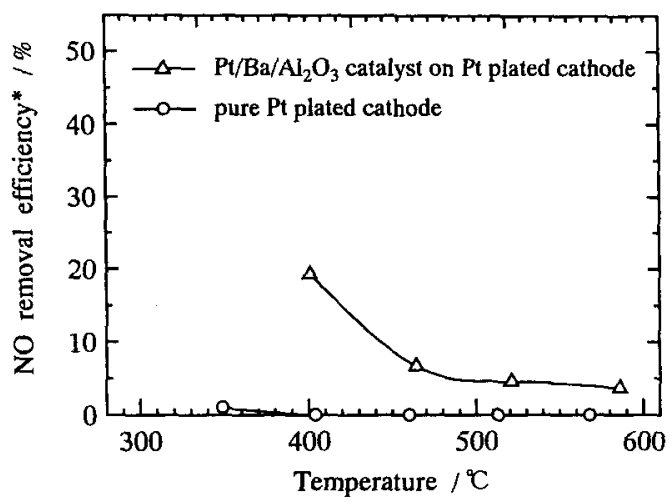

Fig. 8 Temperature dependence of NO removal efficiency* for the cell with pure $\mathrm{Pt}$ cathode and the cell with $\mathrm{Pt} / \mathrm{Ba}$ / $\mathrm{Al}_{2} \mathrm{O}_{3}$ catalyst on Pt cathode. Feed gas: $1000 \mathrm{ppm} \mathrm{NO}$ and $8 \% \mathrm{O}_{2}$ in $\mathrm{He}$. Current density: $2.4 \mathrm{~mA} \mathrm{~cm}^{-2}$. ${ }^{*} \mathrm{NO}$ removal efficiency $=$ Removed NO/Supplied NO.

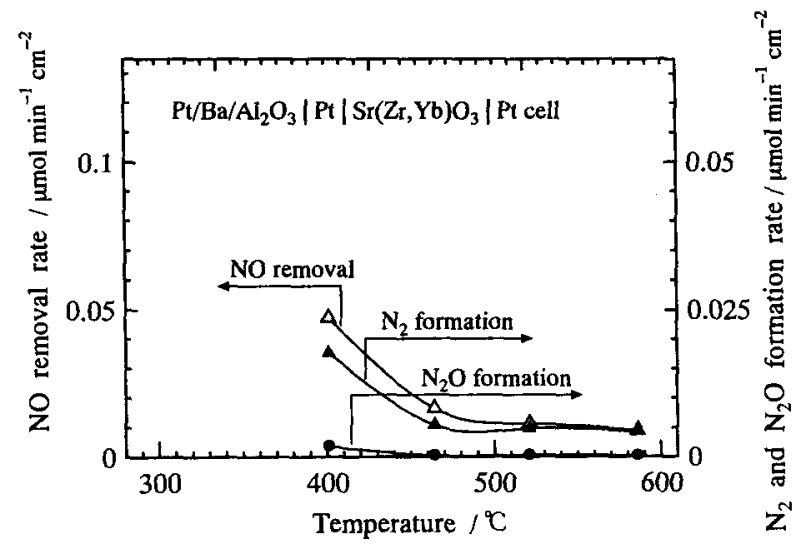

Fig. 9 Temperature dependence of NO removal rate, $\mathrm{N}_{2}$ and $\mathrm{N}_{2} \mathrm{O}$ formation rate for the cell with $\mathrm{Pt} / \mathrm{Ba} / \mathrm{Al}_{2} \mathrm{O}_{3}$ catalyst. Feed gas: $1000 \mathrm{ppm} \mathrm{NO}$ and $8 \% \mathrm{O}_{2}$ in He. Current density: $2.4 \mathrm{~mA} \mathrm{~cm}^{-2}$.

efficiency and $\mathrm{N}_{2}$-formation rate of this cell with the Pt/ $\mathrm{Ba} / \mathrm{Al}_{2} \mathrm{O}_{3}$ catalyst were higher than those of the cell with "Pt sponge $+\mathrm{Sr} / \mathrm{Al}_{2} \mathrm{O}_{3}$ " catalyst previously reported. ${ }^{19}$ ) About $82 \%$ of the removed NO was reduced to $\mathrm{N}_{2}$ and $\mathrm{N}_{2} \mathrm{O}$ at $400^{\circ} \mathrm{C}$ as shown in Fig.9. The rest (18\%) of the removed NO is considered to be absorbed into the catalyst because alkaline-earth elements such as $\mathrm{Ba}$ and $\mathrm{Sr}$ are known to absorb $\mathrm{NO}$ and to form nitrate, such as $\mathrm{Ba}$ $\left(\mathrm{NO}_{3}\right)_{2}$ and $\mathrm{Sr}\left(\mathrm{NO}_{3}\right)_{2}$, when $\mathrm{O}_{2}$ coexists. ${ }^{22-24)}$

The dependence of NO-removal rate and $\mathrm{N}_{2-}$ and $\mathrm{N}_{2} \mathrm{O}$ formation rate on current density at $400^{\circ} \mathrm{C}$ is shown in Fig.10. When the cell with the $\mathrm{Pt} / \mathrm{Ba} / \mathrm{Al}_{2} \mathrm{O}_{3}$ catalyst was used, the NO-removal rate and the $\mathrm{N}_{2}$ and $\mathrm{N}_{2} \mathrm{O}$ formation rate increased with increasing current density. On the other hand, when the cell with the pure Pt cathode $(\bigcirc)$ was used, NO was not removed even at $4 \mathrm{~mA}$ $\mathrm{cm}^{-2}$. All hydrogen produced was thought to react with $\mathrm{O}_{2}$ and not with NO.

Figure 11 shows the cathode potential of the cells used in these experiments. This figure also shows the cathode potential of the cell for producing $\mathrm{H}_{2}$ gas in case pure Ar gas was introduced to the cathode. These results suggest that $\mathrm{H}_{2}$ gas might not be produced when the cell with the $\mathrm{Pt} / \mathrm{Ba} / \mathrm{Al}_{2} \mathrm{O}_{3}$ removed $\mathrm{NO}$, and that $\mathrm{NO}$ might

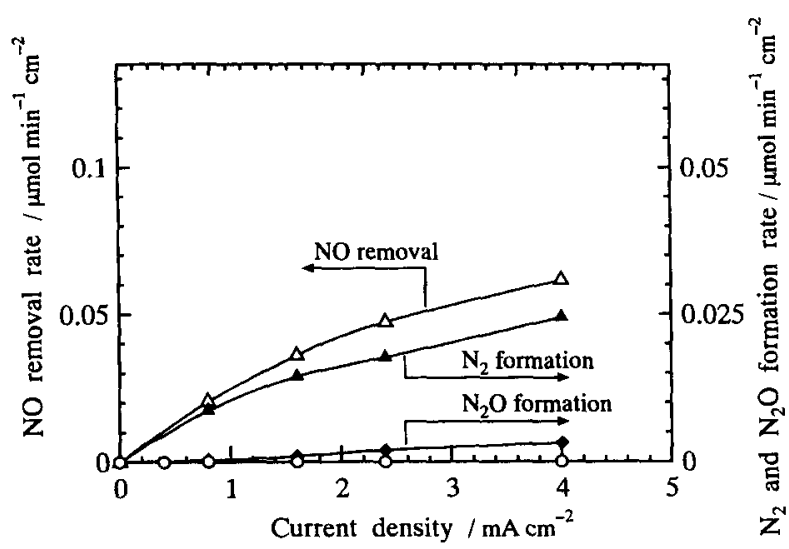

Fig. 10 Change in $\mathrm{NO}$ removal rate, $\mathrm{N}_{2}$ and $\mathrm{N}_{2} \mathrm{O}$ formation rate with current density. Feed gas: $1000 \mathrm{ppm}$ NO and $8 \%$ $\mathrm{O}_{2}$ in He. Temp.: $400^{\circ} \mathrm{C}$. $\triangle$ : NO removal rate of $\mathrm{Pt} / \mathrm{Ba} / \mathrm{Al}_{2} \mathrm{O}_{3}$ | $\mathrm{Pt}\left|\mathrm{Sr}(\mathrm{Zr}, \mathrm{Yb}) \mathrm{O}_{3}\right| \mathrm{Pt}$ cell, $\Delta$ and $\bullet: \mathrm{N}_{2}$ and $\mathrm{N}_{2} \mathrm{O}$ formation rate of $\mathrm{Pt} / \mathrm{Ba} / \mathrm{Al}_{2} \mathrm{O}_{3}|\mathrm{Pt}| \mathrm{Sr}(\mathrm{Zr}, \mathrm{Yb}) \mathrm{O}_{3} \mid \mathrm{Pt}$ cell, $\mathrm{O}$ : NO removal rate of $\mathrm{Pt}\left|\mathrm{Sr}(\mathrm{Zr}, \mathrm{Yb}) \mathrm{O}_{3}\right| \mathrm{Pt}$ cell.

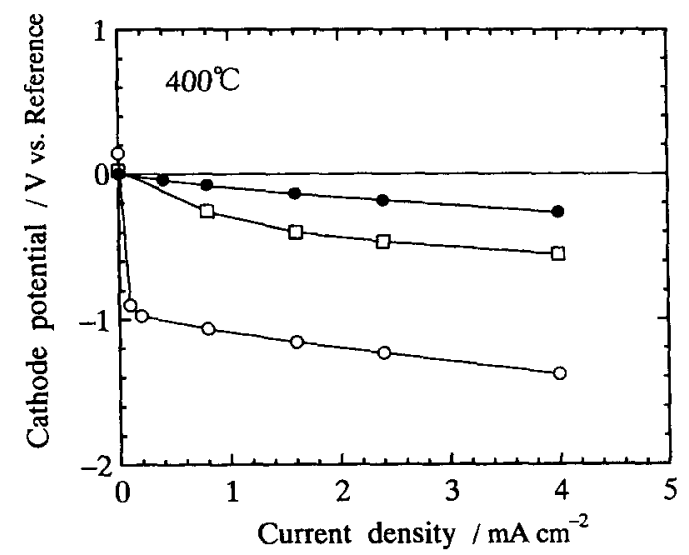

Fig. 11 Current dependence of cathode potential at $400^{\circ} \mathrm{C}$. $\mathrm{O}$ : pure Pt cathode (Feed gas: pure $\mathrm{Ar}, \mathrm{H}_{2}$ production), $\mathrm{O}$ pure $\mathrm{Pt}$ cathode (Feed gas: $8 \% \mathrm{O}_{2}$ and $1000 \mathrm{ppm} \mathrm{NO}$ in $\mathrm{He}$ ), $\square: \mathrm{Pt} / \mathrm{Ba} / \mathrm{Al}_{2} \mathrm{O}_{3}$ catalyst on $\mathrm{Pt}$ plated cathode (Feed gas: $8 \%$ $\mathrm{O}_{2}$ and 1000 ppm NO in $\mathrm{He}$ ).

be reduced electrochemically by proton or chemically by atomic hydrogen adsorbed on Pt. Furthermore, when He gas containing $\mathrm{NO}$ and $\mathrm{O}_{2}$ was introduced into the cathode, the cathode potential of the cell with the $\mathrm{Pt} / \mathrm{Ba}$ / $\mathrm{Al}_{2} \mathrm{O}_{3}$ catalyst was lower than that of the cell with the pure $\mathrm{Pt}$ cathode. This indicates that the $\mathrm{Pt} / \mathrm{Ba} / \mathrm{Al}_{2} \mathrm{O}_{3}$ catalyst inhibited the reaction between $\mathrm{O}_{2}$ and proton.

As mentioned above, $\mathrm{O}_{2}$ should be necessary for the absorption of $\mathrm{NO}$ into $\mathrm{Ba}$ and for the formation of $\mathrm{Ba}\left(\mathrm{NO}_{3}\right)_{2}$ according to equation (9).

$$
\mathrm{BaO}+2 \mathrm{NO}+3 / 2 \mathrm{O}_{2} \longrightarrow \mathrm{Ba}\left(\mathrm{NO}_{3}\right)_{2}
$$

It is considered that the reduction of $\mathrm{O}_{2}$ by proton was inhibited because $\mathrm{O}_{2}$ was used for the absorption of $\mathrm{NO}$ into $\mathrm{Ba}$.

If the absorption of NO into $\mathrm{Ba}$ is not involved in the $\mathrm{NO}$ reduction, NO will be reduced until all $\mathrm{Ba}$ absorbs $\mathrm{NO}$ to form $\mathrm{Ba}\left(\mathrm{NO}_{3}\right)_{2}$ and $\mathrm{O}_{2}$ reduction is started. Considering the flow rate of $\mathrm{NO}$ gas fed into the cathode and the amount of the $\mathrm{Pt} / \mathrm{Ba} / \mathrm{Al}_{2} \mathrm{O}_{3}$ catalyst, it will take three 
hours for the conversion of all $\mathrm{Ba}$ into $\mathrm{Ba}\left(\mathrm{NO}_{3}\right)_{2}$. However, when this NO reduction experiment was repeated with the same cell for more than three hours, the same results (NO-removal efficiency, $\mathrm{N}_{2-}$ and $\mathrm{N}_{2} \mathrm{O}$-formation rate) were obtained. Therefore, the possible reaction cycle is: (i) NO is absorbed into $\mathrm{Ba}$, (ii) absorbed NO is reduced to $\mathrm{N}_{2}$ or $\mathrm{N}_{2} \mathrm{O}$ by proton or atomic hydrogen, (iii) $\mathrm{Ba}$ is again formed, acting as the NO absorption site. In this case, the related electrochemical reaction will be written as equation (6). However, $\mathrm{Ba}$ in the $\mathrm{Pt} / \mathrm{Ba} / \mathrm{Al}_{2} \mathrm{O}_{3}$ catalyst did not directly contact with the protonic conducting electrolyte because this catalyst was laid on the Pt plated electrode. Therefore, the possible NO reduction mechanism is the chemical reaction with atomic hydrogen rather than the electrochemical reaction with proton. Figure 12 shows a schematic diagram of NO reduction mechanism using the steam electrolysis cell with the Pt/ $\mathrm{Ba} / \mathrm{Al}_{2} \mathrm{O}_{3}$ catalyst under $\mathrm{O}_{2}$-rich atmospheres.

From these results, this new method for NO reduction using a steam electrolysis cell has been verified. Because this method can produce hydrogen as a reducing agent of NO by steam electrolysis, it will be expected that this cell can be applied to reduce NO in the exhaust gases of lean-burn engines containing a small amount of the reductive components such as $\mathrm{CO}$ and hydrocarbons. Further studies in this field are needed to improve the performance of this cell as a NO-removal device.

\section{Conclusion}

A steam electrolysis cell was constructed using a perovskite-type protonic conductor, $\mathrm{SrZr}_{0.9} \mathrm{Yb}_{0.1} \mathrm{O}_{3-\alpha}$, as an electrolyte. The present system efficiently produced $\mathrm{H}_{2}$ by steam electrolysis in the temperature range from 400 to $600^{\circ} \mathrm{C}$. When gases containing NO were supplied to the cathode, NO was removed effectively. The reduction products were $\mathrm{N}_{2} \mathrm{O}, \mathrm{N}_{2}$ and $\mathrm{NH}_{3}$ depending on current density. Because the cathode potentials of the cell for reducing NO were higher than those of the cell for producing $\mathrm{H}_{2}$, NO is considered to be reduced by proton or atomic hydrogen. Combining the $\mathrm{Pt} / \mathrm{Ba} / \mathrm{Al}_{2} \mathrm{O}_{3}$ catalyst with this electrolysis cell made it possible to reduce NO even in oxidizing atmospheres. The reduction of $\mathrm{O}_{2}$ might be inhibited due to the absorption of $\mathrm{NO}$ and $\mathrm{O}_{2}$ into $\mathrm{Ba}$, and the absorbed $\mathrm{NO}$ into $\mathrm{Ba}$ might be reduced

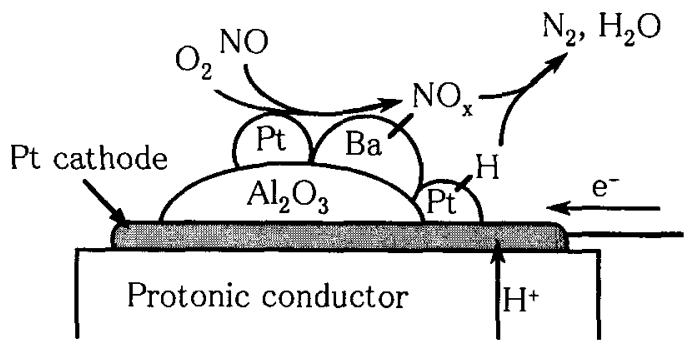

Fig. 12 Schematic diagram of NO reduction using a steam electrolysis cell with $\mathrm{Pt} / \mathrm{Ba} / \mathrm{Al}_{2} \mathrm{O}_{3}$ catalyst. to $\mathrm{N}_{2}$ by atomic hydrogen.

\section{Acknowledgement}

The authors are grateful to TYK corp. for supplying electrolytes and to Dr. Y. Morimoto for useful discussion.

\section{References}

1) H. Iwahara, Solid State Ionics, 86-88, 9 (1996).

2) H. Uchida, H. Yoshikawa, and H. Iwahara, Solid State Ionics, 34, 103 (1989).

3) H. Uchida, H. Yoshikawa, T. Esaka, S. Ohtsu, and H. Iwahara, Solid State Ionics, 36, 89 (1989).

4) N. Sata, K. Hiramoto, and M. Ishigame, Physical Review $B, 54,15795$ (1996).

5) W. Münch, G. Seifert, K. D. Kreuer, and J. Maier, Solid State Ionics, 86-88, 647 (1996).

6) T. Yajima and H. Iwahara, Sensors and Actuators B, 5, 145 (1991).

7) H. Iwahara, H. Uchida, K. Ogaki, and H. Nagato, J. Electrochem. Soc., 138, 295 (1991).

8) T. Yajima, K. Koide, H. Takai, N. Fukatsu, and H. Iwahara, Solid State Ionics, 79, 333 (1995).

9) N. Kurita, N. Fukatsu, S. Miyamoto, F. Sato, H. Nakai, K. Irie, and T. Ohashi, Metall. Mater. Trans. B, 27, 929 (1996).

10) N. Fukatsu, N. Kurita, T. Ohashi, and K. Koide, Solid State Ionics, 113-115, 219 (1998).

11) H. Iwahara, H. Uchida, and S. Tanaka, Solid State Ionics, 9/10, 1021 (1983).

12) H. Iwahara, H. Uchida, and S. Tanaka, J. Appl. Electrochem., 16, 663 (1986).

13) H. Iwahara, T. Yajima, T. Hibino, and H. Ushida, J. Electrochem. Soc., 140, 1687 (1993).

14) H. Iwahara, T. Yajima, and H. Ushida, Solid State Ionics, 70/71, 267 (1994).

15) N. Taniguchi, E. Yasumoto, and T. Gamo, J. Electrochem. Soc., 143, 1886 (1996).

16) S. Hamakawa, T. Hibino, and H. Iwahara, J. Electrochem. Soc., 140, 459 (1993).

17) S. Hamakawa, T. Hibino, and H. Iwahara, J. Electrochem. Soc., 141, 1720 (1994).

18) T. Hibino, S. Hamakawa, T. Suzuki, and H. Iwahara, $J$. Appl. Electrochem., 24, 126 (1994).

19) T. Kobayashi, S. Morishita, K. Abe, and H. Iwahara, Solid State Ionics, 86-88, 603 (1996).

20) T. Yajima, H. Suzuki, T. Yogo, and H. Iwahara, Solid State Ionics, 51, 101 (1992).

21) M. J. Scholten, J. Schoonman, J. C. Miltenburg, and H. A. J. Oonk, Solid State Ionics, 61, 83 (1993).

22) N. Miyoshi, S. Matsumoto, K. Katoh, T. Tanaka, J. Harada, N. Takahashi, K. Yokota, M. Sugiura, and K. Kasahara, SAE paper, 950809 (1995).

23) N. Takahashi, H. Shinjoh, T. Iijima, T. Suzuki, K. Yamazaki, K. Yokota, H. Suzuki, N. Miyoshi, S. Matsumoto, T. Tanizawa, T. Tanaka, S. Tateishi, and K. Kasahara, Catalysis Today, 27, 63 (1996).

24) M. Machida, K. Yasuoka, K. Eguchi, and H. Arai, J. Chem. Soc. Chem. Commun., 1165 (1990). 